\title{
THE RECONSTRUCTION OF POLICY RELATED TO THE OPTIMISATION ON NATIONAL SOCIAL SECURITY PUBLIC MEMBERSHIP
}

\author{
Nabitatus Sa'adah \\ Faculty of Law, Universitas Diponegoro \\ nabitatuss@gmail.com
}

\begin{abstract}
One of the people's needs in terms of effort to manifest the purpose of the state which is to establish national wellbeing is by providing social security. Social security is a form of social protection to meet citizens' basic needs. Associated with the implementation of national social security, the government obligates its citizens to participate in the program. However, the fact was there are still many citizens which are reluctantly participating in the program. It is leading to funding collection to be not optimal and affecting the implementation of social security. The research is adopting normative approach, which is stressed on the secondary data. The research specification is an analytic description with qualitative analysis. The national social security is a compulsory program for all of the Indonesian citizens particularly for the independent level, however, not all have joined it particularly self-referred participants. Several aspects causing this problematic program, such as the lack of people's awareness. The lack of people discipline toward the payment, ineffective sanctions and lack of service, are proved with the abundant number of payment arrears by independent participants. The reconstruction of optimization of National Social Security Program is managed with the improvement of legal substance, legal structure and legal culture.
\end{abstract}

Keywords: BPJS; National Social Security

\section{Introduction}

Establishing national well-being is the consequence of adopting a concept of State of Law. In the beginning, the concept of State of Law was developed into a formal state of law, where the role of the state is insignificant. The demands for the state roles in formal law was not substantial. The state, in the concept of the state of law, was only ordered to be present to provide security to the people, therefore the task of the state is called as the night watchman (Nachtwaker Staat) ${ }^{1}$. The state of the law in the context of its formality is separating between the state and its people, the country does not interfere with its people's life aspects, whether in economics, social, culture and etc., as a result of the state interference, can trim the individual independence. The laissez-faire principle is the motto adopted in the classic state of $\mathrm{law}^{2}$. The existence of the state restrictions in practice is considered to torture the life of the state.

1 Elviandri.et.al, "Quo Vadis Negara Kesejahteraan Meneguhkan Ideologi, Welfare Sate Negara Hukum Kesejahteraan Indonesia,” Mimbar Hukum 31, no. 2 (2019): 257.

2 S Maarif, "Dinamika Peran Negara Dalam Proses Liberalisasi Dan Privatisasi," Jurnal Kebijakan dan Administrasi Publik 10, no. 2 (2006): 102. 
The failure of Nachwaker Staat implementation causes the emergence of ideas to correct and perfect it towards the state welfare ${ }^{3}$, which places the government as the party responsible to the people's welfare or called the concept of welfare state ${ }^{4}$. The concept of welfare state expects the state not only maintains its people's security but also actively regulates and interferes on its people's affairs to create people's welfare.

Regarding the state of law, Indonesia also adopts the state of law which has special traits that different from other countries, although few of the general principles are also adopted ${ }^{5}$. One of the state purposes, as stipulated in the preamble of the 1945 Constitution of The Republic of Indonesia, states that the state of Indonesia shall manifest general welfare for its people, it shows that Indonesia adopts the state welfare concept.

Welfare state, briefly, is define as a state responsible to guarantee the minimum welfare standard of each citizen. According to Wolfe, the government in national well-being is the highest organization which is morally demanded to be responsible on fulfilling its citizens' welfare $^{6}$. A law issued by the government to manifest general welfare is organizing social security program, as regulated in the Law no. 40 of 2004 on National Social Security System. The implementation of social security is the duty of the state to provide social protection for its people $^{7}$.Article 1 points 1 the Law no. 40 of 2004 states social security is a form of social protection to guarantee all citizens receiving decent basic life needs. Therefore, BPJS has a mission to fulfill the constitutional rights of every person regarding social security ${ }^{8}$.

The social security program administered by the Social Insurance Administration Organization (BPJS) is regulated by Law No.24 of 2011 on BPJS, there are two versions of BPJS: BPJS Kesehatan and BPJS Ketenagakerjaan. BPJS is manifested with principles, such as mutual cooperation, and participation is mandatory. Article 14 the Law no. 24 of 2011 regulated that everyone including expatriates who are working at least six months must enroll in the social

3 Aloysius R Endah, “Indonesia:Negara Hukum Yang Berdasarkan Pancasila,” Jurnal SHN, FH Unnes 2, no. 1 (2016): 533-542.

4 Ridwan HR, Hukum Administrasi Negara, 14th ed. (Jakarta: Raja Grafindo, 2018).

5 Haposan Siallagan, "Penerapan Prinsip Negara Hukum Di Indonesia," Sosiahumaniora 18, no. 2 (2016): 131137.

6 Wina Puspitasari, "Perlindungan Hukum Terhadap Pengetahuan,Tradisional Dengan Sistem Perizinan, Perspektif Negara Kesejahteraan," PADJADJARAN, Jurnal Ilmu Hukum (Journal of Law) 1 (2014): 38, http://download.garuda.ristekdikti.go.id/article.php?article=447564\&val=9475\&title=Perlindungan Hukum Terhadap Pengetahuan Tradisional dengan Sistem Perizinan Perspektif Negara Kesejahteraan.

7 Heru Purnawan, "Transformasi PT. Jamsostek (PERSERO) Menjadi Badan Penyelenggara Jaminan Sosial (BPJS) Ketenagakerjaan Di Kantor Cabang,” Jurnal Publika 2, no. 3 (2014).

8 Regina Supeno, Desie M D Warouw, and Herry Mulyono, "Peran Komunikasi BPJS Kepada Pelaku Usaha Tentang Jaminan Sosial Ketenagakerjaan (Studi Pada Pelaku Usaha Di Wilayah Kelurahan Mapanget) Oleh," Acta Diurna, no. 2 (2016). 
security program. Moreover, its funding concept prioritizing mutual cooperation through the social insurance system. This system means people are expected to help each other. The fund from healthy participants is used to help other participants who need healthcare services.

The success of the social security program highly depends on people's awareness on participation. Sadly, not everyone has registered particularly self-reserved participants, on the other hand the discipline level of payment is low $^{9}$. It indirectly affecting BPJS's cash flow and causing budget deficit which had occurred in several years.

In the last few years, the program has suffered from the budget deficit. In 2017, BPJS had a deficit of 10,98 trillion Rupiah ${ }^{10}$. It had to admit that there are several factors causing it i.e the imbalance cashflow, low number of self-reffered participants, and low participant payment disclipline, these are interesteng for research.

This research is aimed to find policy reconstruction that able to optimize people's participation in national social security and its sustainability in an attempt to manifest welfare. Problems: 1) What are the problems related to optimization of people's participation in national social security?; 2) How can policy reconstruction optimize the BPJS participations?

\section{Methods}

This research is categorized as normative juridical or doctrinal law research, law is concepted as normative symptoms differ from social symptoms ${ }^{11}$. The approach in the research is a doctrinal approach, conducted by statute approach, historical approach, comparative approach and conceptual approach ${ }^{12}$.

Research specification is description analytic, which is a research method that describes the fact, which are analyzed with relevant theorie. This research outlines problem descriptions related to national social security participations and analyzes using the secondary data with literature study.

\footnotetext{
Kompas.com, "Tunggakan Iuran Capai 15 Triliun, Peserta Mandiri BPJS Kesehatan Diharapkan Disiplin Membayar," Kompas.com, 2019.

10 CNN Indonesia, "Pangkal 'Penyakit' Defisit BPJS Kesehatan” (2018, September 2018).

11 Ahmad Zuhdi Muhdlor, "Perkembangan Metode Penelitian Hukum,” Jurnal Hukum Dan Peradilan 1 (2012).

12 Peter Mahmud Marzuki, Penelitian Hukum (Edisi Revisi) (Jakarta: Kencana Prenada Media Group, 2017).
} 


\section{Results and Discussion}

\subsection{The Implementation of National Social Security in the Concept of Welfare State}

One of the state purposes, as stipulated in the Preamble of the 1945 Constitution of The Republic of Indonesia, states that the state of Indonesia shall manifest general welfare for its people. Based on the mandate of the Preamble of 1945 Constitution of The Republic of Indonesia, one of the attempts performed by the government to provide people's welfare is implementing a social security program.

The issue of the Law No. 40 of 2004 on the National Social Security System is a proof of the government persistence in actualizing the National Social Security. Article 3 of Law No. 4 of 2004 states that the purpose of the National Social Security is providing security over basic needs for the individual and his family members as well, to have a decent life. The forming of the National Social Security Program is also a mandate of Article $28 \mathrm{H}$ of the 1945 Constitution of The Republic of Indonesia; in essence that social security and security of human selfdevelopment as a whole and dignified are the constitutional rights of every person. Moreover, the state has a responsibility to guarantee protection, custody, and maintenance to its citizens without any exception particularly to citizens who live in poverty ${ }^{13}$.

In an attempt to implement the National Social Security Program, Law No. 40 of 2004 gives mandate to form the Social Insurance Administration Organization, which its formation shall be based on the Act. The implementation of Social Insurance Administration Organization which must be based on the act is intended not only for the protection of a better legal certainty but also for achieving agreement from citizens through the legislative body which is the people's representation. This should be implemented considering that the national social security is a program which must be followed by all citizens.

The mandate to form the Social Insurance Administration Organization was being followed with the issue of Law No.24 of 2011 on the Social Insurance Administration Organization to be called BPJS. It is a legal entity which is formed for implementing social security program to guarantee the citizens' constitutional rights through community development ${ }^{14}$.

As mentioned previously, BPJS consists of BPJS Kesehatan (healthcare security), where its scope of work is performing healthcare security program, and BPJS Ketenagakerjaan (social

13 Nindy Waras Sayekti, "Analisis Badan Penyelenggara Jaminan Sosial (BPJS) Transformasi BUMN Penyelenggara Jaminan Sosial,” Jurnak Ekonomi dan Kebijakan Publik 1, no. 1 (2010).

14 Didi Sukardi, "Pengelolaan Dana Badan Penyelenggara Jaminan Sosial (BPJS) Kesehatan Dalam Perspektif Hukum Islam,” Mahkamah ( Jurnal Kajian Hukum Islam\} 1, no. 1 (2016). 
security), which provides security on working accident protection, old age protection, pension protection, and Death Protection.

Before the issue of Laws of BPJS, there are already several state owned enterprises that carried out BPJS's scope of work, e.g.: (a) PT. ASKES (Persero), the abbreviation from Asuransi Kesehatan Indonesia, a limited liability company that performed healthcare security program; (b) PT. Jaminan Sosial Tenaga Kerja (Persero), abbreviated PT. Jamsostek, a limited liability company that provided security on working accident protection, old age protection, and pension protection; (c) PT. ASABRI (Persero), a limited liability company servicing in insurance and pension protection for Indonesian National Armed Forces and Indonesia National Police (TNI/POLRI); and (d) PT. Dana Tabungan dan Asuransi Pegawai Negeri (Persero), abbreviated PT TASPEN, a limited liability company that provides pension for civil servant retirees and their widows/widowers.

After the issue of Law No 24 of 2011, those corporations transformed into Badan Penyelenggara Jaminan Sosial (BPJS), while PT ASKES (Persero) remodeled as Badan Penyelenggara Jaminan Sosial Kesehatan, and PT JAMSOSTEK (Persero). Moreover, the pension and old age protection programs of PT ASABRI (Persero) and PT TASPEN, are transferred to BPJS.

Associated to the matter, BPJS is organized within national scope with social insurance and equity principles. In general, insurance is a reciprocal contract, in which an individual or entity receives financial protection or reimbursement against losses from an insurance company. The insurer or insurance company engages to endure the risk or reimburse such amount of money to the insured. While the insured engages to make a sum of payment (premium) to the insurer.

The definition of insurance, referring to Article 246 of KUHD, is a contract where the insurer engages to the insured by receiving a premium, as an exchange of reimbursement due to a loss, damage, injury or the loss of expected profit, which may be suffered due to an uncertain event. According to the definition, the insurance elements are as follows ${ }^{15}$ : (a) The existence of an insurance company as a guarantor and an insurance participant as an insured; (b) Premium, money paid by an insurance member (the insured); (c) A promised event which is still uncertain to occur; and (d) Achievements which should be fulfilled by the guarantor as promised.

15 Adjie Assyafei Solaiman, "Perlindungan Hukum Pembeli Polis Asuransi Online," Hukum Bisnis, Universitas Noratama Surabaya 2, no. 2 (2018): 57. 
Those four elements of insurance must be inserted and clearly written in the contract. If one of the elements is missing, then it is unable to be called insurance contract or polis.

Essentially, for the insured, insurance is purposed to cover losses costs occurred when an undesirable event happens, and when he pays the premium the event hasn't happened yet and it might never happen. As for the insurance guarantor the premium is able to be invested as the capital of business development so as to generate profits.

\subsection{The Principles of National Social Security System Implementation.}

The Social security program carried out by BPJS, although in principle used the concept insurance but there are things that differentiate from insurance program in general. BPJS is not formed for profit. The premiums paid by participant are managed by BPJS, the result of which are used maximally for the benefit of participant.

There are several principles which are used as the basis of national social security program implementation, namely:

Mutual Cooperation Principle; is a principle in accordance with Pancasila that the implementation of the national security program is carried out with the principle of mutual cooperation, which means the contributions from the able participants can be used to help finance for the disadvantaged participants, the healthy participants can help the funding of sick participants, and likewise the low risk participants can help the high risk participants

Nonprofit Principle, unlike other insurance programs, the management of incoming fund in BPJS is not intended for seeking profit, but it is utilized as much as possible for the benefits of the participants. The incoming funds, such as trust funds, profit funds from development or budget surplus are utilized as much as possible for its participants needs.

All of the fund's management, both from participant contributions and from development proceeds, are managed with the principles of openness, prudence, accountability, effectiveness and efficiency. The implementation of these principles is carried out by BPJS by making financial accountability periodically and conducting both internal and external audit supervision.

Another principle applied in the implementation of social security is the principle of portability, meaning that the implementation of national social security is a sustainable security program, the movement of dwellings while still within the territory of the Republic of Indonesia and the national security work continues to follow. 
The principle of membership is mandatory; all of the citizens of Indonesian are required to take part in this national security implementation program so that all citizens are protected. The obligation to participate is carried out in accordance with the financial capabilities of the citizens. The citizens can choose the amount of the determined premium layer which is adjusted to their economic capacity. In general, the amount of premium does not affect the service delivery; the only difference is the room facilities according to the class chosen if the participant is hospitalized.

The principle of mandated funds, the premium funds that go to BPJS, are entrusted funds which are mandated by the community as participants so they need to be properly maintained and managed and used as an effort to optimize these funds for the welfare of the participants. The results of fund management are all used for developing the program and the results are used for the benefits of the participants.

Based on several principles of the implementation of the national social security system, it can be concluded that in principle the implementation of the social security is carried out cooperatively through mandatory participation and is not intended to seek profit but is used for the benefits of participants.

\subsection{Duties, Rights, and Authorities of Badan Penyelenggaraan Jaminan Sosial}

As an institution that carries out the national social security, BPJS has several duties, as follows: (a) Performing payments billing; (b) Allocating the social security funds for short and long term investments with the consideration of liquidity and prudence aspects; (c) Performing supervision and inspection towards participants and employer's compliance in fulfilling their obligations according to the statutory regulations; (d) Making an agreement with the health facility regarding the amount of payment for the health facility; (e) Arranging or terminating work contracts with healthcare service provider; (f) Imposing administration sanction to participants and employer who are not fulfilling their responsibilities; and (g) Reporting the employees to the authorities regarding their incompliances of payments.

BPJS as the Social Security Administering Body has the rights to, among others, obtain operational funds to administer programs sourced from social security funds and or other sources, and has the right to obtain the results of monitoring and evaluation of the implementation of social security programs from the National Social Security Board every six months. 
The obligations of BPJS include: (a) Providing single identity number to its participants; (b) Developing social security fund assets and BPJS assets as much as possible for the benefits of participants; (c) Providing information through printed and electronic media regarding to its financial condition, wealth, and development results; (d) Providing benefits to all participants; (e) Providing information to participants regarding the procedures for obtaining their rights and obligations; (f) Providing information to participants regarding to old age protection balance and its development once in a year; (g) Providing information to participants regarding to the amount of pension right once in a year; (h) Performing the bookkeeping according to the accounting standards; and (i) Reporting every program to the President including the financial condition periodically every six (6) months.

As the social security organizer, BPJS is given the authority to manage the assets of both BPJS assets and Social Security Fund assets. Both of these assets must be separated in management and the Social Security Fund assets are not BPJS assets.

BPJS assets can be sourced from: (a) The initial capital from the government namely the state's assets which are separated and not divided into shares; (b) the transfer of assets of a StateOwned Enterprise that runs the national security program; (c) Proceeds from BPJS asset development; (d) Operational funds taken from the Social Security Fund; and (e) Other legal sources in accordance with statutory regulations. The social fund assets are sourced from: (a) Social security contributions include contribution assistance; (b) Proceeds from the development of the Social Security Fund; (c) The results of transfer of social security program assets which become the right of participants from State-Owned Enterprises; and (d) Other legal sources.

Based on the types of assets above, it can be concluded that the assets of BPJS are BPJS independent assets originating from the sources above which among others are derived from initial capital obtained from the government. Both BPJS Kesehatan and BPJS Ketenagakerjaan were given a maximum initial capital of Rp. 2,000,000,000,000 (two trillion Rupiah). This initial capital represents the separated state assets. The state assets separated from the State Budget $(\mathrm{APBN})$ is used for capital participation.

In addition to independent assets, BPJS also manages the Social Security Fund Assets. The assets of social security funds are the assets derived from participants premium, which must be separated from BPJS independent assets. The assets of social security funds are assets derived from funds belonging to all participants from the accumulation of participants and the results of their development. 


\subsection{Some Problems Regarding BPJS Participation Optimization}

As described above in order to realize the welfare of the people, the government organized a national social security system that aims to provide of protection and social welfare for all people. The national social security is the security provision of decent basic needs of life for each participant, which includes health insurance, employment protection that covers insurance related to occupational accident insurance, old age insurance, pension insurance and death protection.

One of the National Social Insurance System programs implemented by the government as stated above is performed through National Health Insurance program. National Health Insurance is a program created by the government in order to implement health development by providing health protection to the citizens to fulfill their basic health needs. The government involves the citizens in the implementation of national insurance program by applying mutual cooperation and nonprofit principles, which is carried out by applying the concept of insurance.

The effort performed by the government to involve citizens in the program is followed up by making regulations which require all citizens to participate as participants by paying membership fees. Article 16 of BPJS Law requires that anyone other than employers, workers and recipients of contribution assistance who fulfill the membership requirements in social security to register themselves and their family members as BPJS participants. The participants are asked to pay membership fees in accordance with what is determined or by selecting the amount of contribution according to the treatment room services determined for participants not receiving wages or not workers.

The memberships of BPJS are divided as follows: (1) Worker; (2) Employer; (3) NonEmployed Participants, not employer or called self-referred participants; and (4) Premium Assistance Recipients. According to the Presidential Regulation No 82, 2018 regarding the Health Insurance, the criteria of participants are described in more detail as follows: (1) Premium Assistance Recipients; and (2) Non-Premium Assistance Recipients.

The participants of premium assistance recipient of health security are the poor and the disadvantaged people as a program of health security. The membership fees of premium assistance recipients is paid by the Central Government. The Non-Premium Assistance Recipients consist of: (a) Wage Recipient Worker (PPU) namely anyone who works for an employer and receives a salary or wage; (b) Non- Wage Recipient Worker (PBPU) namely anyone who works or thrives at his own risk; and (c) Non-Worker, namely anyone who is not in 
the categories of PPU, PBPU, PBI of Health Insurance and citizens who are registered by Regional Government.

Basically, all citizens of Indonesia including foreign citizens who already works more than 6 (six) months in Indonesia are required to attend social security programs, especially health insurance programs.

The amount of contribution fees that should be paid by participants is determined as follows : (a) For Premium Assistance Recipients (PBI), the contribution fees of Health Insurance are paid by the Government; (b) The contribution fees for participants of Wage Recipient Workers who work for Government Agencies namely Civil Servants, members of the National Military, members of the National Police, state officials, and Non-Civil Servant of Government Employees are $5 \%$ (five percent) of Salary or Wages per month with the following provisions: $3 \%$ (three percent) is paid by employers and $2 \%$ (two percent) is paid by participants; (c) The contribution fees for participants of Wage Recipient Workers who work for BUMN, BUMD and private sectors are $5 \%$ (five percent) of Salary or Wages per month with the following provisions: 4\% (four percent) is paid by employers and 1\% (one percent) is paid by Participants; (d) The amount of additional contribution fees for additional family members of Wage Recipient Workers consisting of $4^{\text {th }}$ child and so forth, father, mother and parents in-law is $1 \%$ (one percent) of salary or wages per person per month, paid by the wage recipient workers; (e) The contribution fees for other relatives of wage recipient workers (for example siblings/in-laws, house maid, etc.); non-wage recipient worker participants and contribution of non-worker participants; and (f) The contribution fees for participants of non-Wage Recipient, determined by their class classifications.

The funds originating from BPJS participant contributions above are managed as the funds used to carry out health insurance coverage with the insurance system, where participants pay the contributions fees regularly and have the right to receive benefits of protection that are entitled to participants. The benefits in the BPJS Kesehatan include the benefits of health insurance in the form of health services which include the benefits of promotion, preventive, curative and rehabilitative services including medicine services and medical equipment as needed.

The provision of services is differentiated between medical and non-medical services, medical services are provided with the same facilities for all participants not bound by the amount of the contribution fees. All participants have the same rights regarding medical services. The difference in the provision of service facilities is only related to non-medical services, 
namely the accommodative benefits (inpatient rooms) which is adjusted to the scale of payment on the amount of contributions paid.

As described above, the social insurance is implemented with the principle of mutual cooperation, the contribution paid by participants can be utilized to help each other between participants. The healthy participants can help the sick participants; the low-risk participants can help the high-risk participants, and the participants who are able help those who are unable.

The national social security system that has been implemented by BPJS for more or less than 8 years apparently has not been able to be said in line with what was expected even a few years before it was said to be a deficit. One of the problems BPJS's deficit is the unbalance funds, the total contributions is uneven with service fees.

Lack of people's awareness, particularly independent category participants to participate in the national social security membership. Many people in the category of self-referred participants or Non-Wage Recipient Participants (PBPU) who do not participate. Many independent participants who just register when they are sick and there is no consistency in paying contribution fees after declared cured. Below is the membership data obtained from BPJS:

Table 1.

Graph of BPJS participants

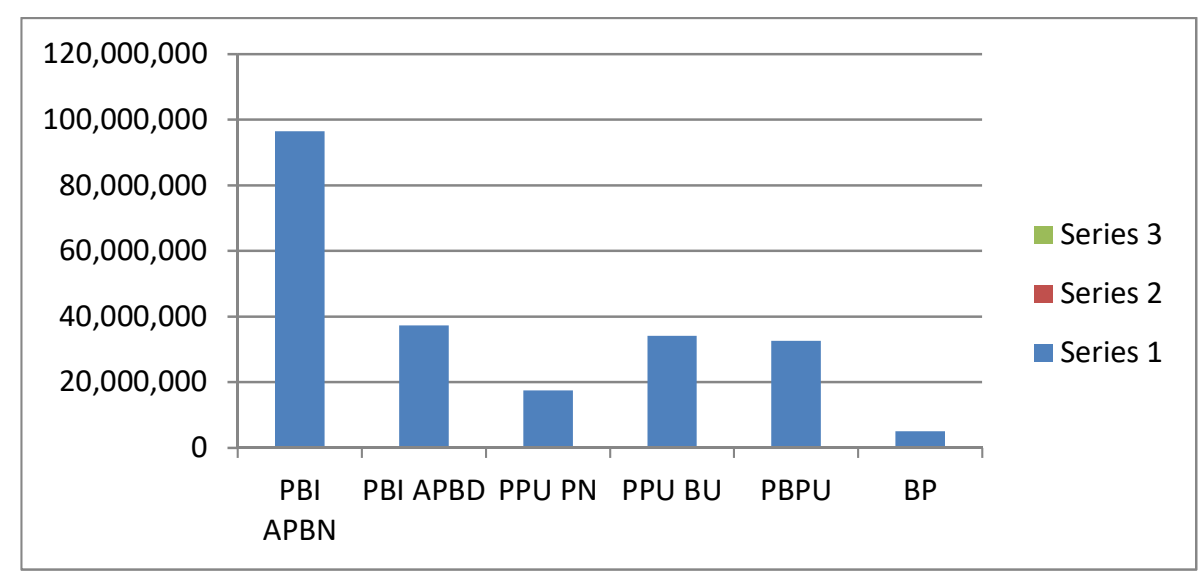

Source : BPJS Kesehatan, August $1^{\text {st }} 2019$

Notes :

1. Total participants of JKN 222.435.719 persons

2. Number of participants receiving healthcare services APBN (PBI-APBN) 96.696.683 persons 
3. Number of participants receiving healthcare services APBND (PBI-APBD) 37.364.257 persons

4. Number of participants of Civil Servants (PPU-PN) 17.716.869 persons

5. Number of participants of Employees, business entity (PPU-BU) 37.364.257 persons

6. Number of participants of entrepreneur (PBPU) 30.487.891 persons

7. Number of non-Wage Recipient participants 5.051250 persons

Based on the data above, the highest number of participants is in the category of participants receiving healthcare services from the Central Government, followed by the participants receiving healthcare services from the Local Government. Contribution Recipient Participants are participants whose contribution fees are paid by either Central Government or Regional Government. If PBI APBN and APBD are combined then the contribution fees of 131.815.452 participants are paid by the government. The total number of participants participating in BPJS membership is 222.435 .719 participants. If the total population of Indonesia is 267.289 .770 people as per $31^{\text {st }}$ December $2019^{16}$, while there is a total of 222.435.719 people participating, then there are still around 44.854.051 citizens who have not participated.

Second, the lack of discipline of self-referred participants in compliance with BPJS contribution payments. The data at the end of 2019 shows the arrears of independent participants are amounted to 22,7 trillion Rupiah, independent participants who actively pay are only about $55,5 \%$. Many of self-referred participants only pay actively when they are sick, and after recovered they do not make payment obligations. Such action in the economic field is called adverse selection. It causes huge loss for BPJS and deficit. Based on data, self-referred claim ratios is $313 \%$ with total 27,9 trillion Rupiah, while the contribution only 8,9 trillion Rupiah ${ }^{17}$.

The problem associated to not optimum of BPJS's self-referred membership is caused by several factors i.e. legal culture problem, where participants disobedience on Law and regulations. People neglect the cooperation principle adopted in the program. Many factors trigger disobedience : first, moral hazard, a tendency to take advantage without obligation; second, low financial capability; third, people mistrust on its Administration's capability to provide excellent services and simple procedure; fourth, law enforcement.

16 https://dukcapil.kemendagri.go.id,

17 kemenku.go.id, 


\subsection{Reconstruction of Participation Optimization Policy}

There are ways to improve BPJS's membership. The system theory according to Lawrence M Friedman is used to analyze and improve existing condition. Lawrence M Friedman says "A legal system in actual operation is a complex organism in which structure, substance and culture interact" $" 18$.

Thus, the non-optimum problem is visible from legal structure, legal substance and legal culture. Problem legal substance is related to the formulation of sanctions. Regarding noncompliant participants, the actual legislation provides the authority to bill the participants. For participants who are in arrears, there is a consequence that the card will be deactivated. Service facilities will not be provided if there are arrears.

Other provision that is too soft for undisciplined participants can be seen as follows; if a participant is in arrears, the participant is only required to pay arrears for a maximum of 24 months without a sanction of fine. A new fine is given if the participant is hospitalized for a period of 45 days after the activation and is subject to a $2.5 \%$ fine, a maximum of Rp.30,000,000. If observed closely, these provisions are harder than the previous regulation, where fine is maximum 12 months. If a participant in class 1 is indiscipline and hospitalized, the participant has to pay Rp. $150,000 \times$ maks. 24 months $=$ Rp. 3,600,000, then he is entitled to receive treatment fee covered. If the participant then hospitalized within 45 days of activation, the consequence will only additional $2,5 \%$ fine from treatment fee. When treatment fee coverage is bigger than the total of fines, it will cause the imbalance between in and outflow therefore harm BPJS.

The policy regarding the sanction implementation is a dilemmatic, considering BPJS concept is a social security instead of a commercial insurance. Social security principle is not prioritize profit but a concept which emphasizes in helping or easing participant. To increase participant obedient, the government can formulate fine policy by classifying the fine on the percentage of fees covered. Single fine percentage can cause injustice and burden BPJS in covering fee for participant who needs large sum of treatment fee.

In addition to fine, the Law gives administrative sanction to citizen, who is not registered in health security, by not giving public service. The administrative sanction is not well implementation. It is caused there is no technical regulation supports and lack of coordination between institutions to implement the sanctions.

18 Lawrance M Friedman, Sistem Hukum Perspektif Ilmu Sosial, Diterjemahkan Oleh M.Khozin (Bandung: Nusa Media, 2013). 
Legal structure problem, such as related to the service. The not-excellent service given, and also the complicated referral system, therefore it needs service improvement. Legal culture problem is the lack of awareness of people to join National Health Security Program. Solutions on the problem are depend on awareness, discipline and desire to help with cooperation principle. Harder sanction impose and service improvement are needed to solve the problem.

\section{Conclusions}

The Government Policy regarding National Social Security Participation Specifically for Health Security, that the citizens of Indonesia are obliged to participate in national social security program. However, there are still many citizens of Indonesia, especially those who are categorized as independent participants, who have not participate in the government's program. The lack of awareness from the citizens in supporting this program becomes one of the reasons of why the implementation of this national social security program does not run optimally. Generally, the citizens just participate in the program when they need health service from the government. The lack of discipline from citizens is proven with the abundant sum of payment arrears from independent participants.

The reconstruction of policy in optimizing the participation of national social security program is able to be performed with a reformulation on sanction system, assertiveness of fine, service improvement and the increase of people awareness.

\section{References}

CNN Indonesia. “Pangkal ‘Penyakit’ Defisit BPJS Kesehatan.” 2018, September 2018.

Elviandri.et.al. “Quo Vadis Negara Kesejahteraan Meneguhkan Ideologi, Welfare Sate Negara Hukum Kesejahteraan Indonesia.” Mimbar Hukum 31, no. 2 (2019): 257.

Endah, Aloysius R. "Indonesia:Negara Hukum Yang Berdasarkan Pancasila.” Jurnal SHN, FH Unnes 2, no. 1 (2016): 533-542.

Friedman, Lawrance M. Sistem Hukum Perspektif Ilmu Sosial, Diterjemahkan Oleh M.Khozin. Bandung: Nusa Media, 2013.

Heru Purnawan. "Transformasi PT. Jamsostek (PERSERO) Menjadi Badan Penyelenggara Jaminan Sosial (BPJS) Ketenagakerjaan Di Kantor Cabang.” Jurnal Publika 2, no. 3 (2014).

HR, Ridwan. Hukum Administrasi Negara. 14th ed. Jakarta: Raja Grafindo, 2018. 
https://dukcapil.kemendagri.go.id. "N."

kemenku.go.id. "No Title."

Kompas.com. "Tunggakan Iuran Capai 15 Triliun, Peserta Mandiri BPJS Kesehatan Diharapkan Disiplin Membayar.” Kompas.com, 2019.

Maarif, S. "Dinamika Peran Negara Dalam Proses Liberalisasi Dan Privatisasi." Jurnal Kebijakan dan Administrasi Publik 10, no. 2 (2006): 102.

Marzuki, Peter Mahmud. Penelitian Hukum (Edisi Revisi). Jakarta: Kencana Prenada Media Group, 2017.

Muhdlor, Ahmad Zuhdi. "Perkembangan Metode Penelitian Hukum." Jurnal Hukum Dan Peradilan 1 (2012).

Puspitasari, Wina. "Perlindungan Hukum Terhadap Pengetahuan,Tradisional Dengan Sistem Perizinan, Perspektif Negara Kesejahteraan.” PADJADJARAN, Jurnal Ilmu Hukum $\begin{array}{lllll}\text { (Journal } & \text { of } & \text { Law) } & 1 & \text { (2014): }\end{array}$ http://download.garuda.ristekdikti.go.id/article.php?article=447564\&val=9475\&title=Perli ndungan Hukum Terhadap Pengetahuan Tradisional dengan Sistem Perizinan Perspektif Negara Kesejahteraan.

Sayekti, Nindy Waras. "Analisis Badan Penyelenggara Jaminan Sosial (BPJS) Transformasi BUMN Penyelenggara Jaminan Sosial.” Jurnak Ekonomi dan Kebijakan Publik 1, no. 1 (2010).

Siallagan, Haposan. “Penerapan Prinsip Negara Hukum Di Indonesia.” Sosiahumaniora 18, no. 2 (2016): 131-137.

Solaiman, Adjie Assyafei. "Perlindungan Hukum Pembeli Polis Asuransi Online." Hukum Bisnis, Universitas Noratama Surabaya 2, no. 2 (2018): 57.

Sukardi, Didi. "Pengelolaan Dana Badan Penyelenggara Jaminan Sosial (BPJS) Kesehatan Dalam Perspektif Hukum Islam.” Mahkamah ( Jurnal Kajian Hukum Islam\} 1, no. 1 (2016).

Supeno, Regina, Desie M D Warouw, and Herry Mulyono. "Peran Komunikasi BPJS Kepada Pelaku Usaha Tentang Jaminan Sosial Ketenagakerjaan (Studi Pada Pelaku Usaha Di Wilayah Kelurahan Mapanget) Oleh.” Acta Diurna, no. 2 (2016). 